\title{
Clinical Relevance of Soluble c-erbB-2 for Patients with Metastatic Breast Cancer Predicting the Response to Second-Line Hormone or Chemotherapy
}

\author{
S. Classen ${ }^{a, e}$ R. Kopp ${ }^{a}$ b K. Possingerc R. Weidenhagen ${ }^{b}$ W. Eiermann ${ }^{d}$ \\ W. Wilmannse
}

aGSF-National Research Center for Environment and Health, and b Department of Surgery, Klinikum Grosshadern, University of Munich, Munich 'Department of Internal Medicine II, Charité, Berlin, and dRot-Kreuz Frauenklinik and eDepartment of Internal Medicine III, Klinikum Grosshadern, University of Munich, Munich, Germany

\section{Key Words}

Metastatic breast cancer - Response to therapy • Soluble erbB-2

\begin{abstract}
Concentrations of soluble c-erbB-2 were determined in the sera of 64 patients with distant metastasis from advanced breast cancer receiving second-line hormone or chemotherapy in comparison to 35 breast cancer patients without detectable recurrent disease and 17 healthy blood donors. The sera of non-metastatic breast cancer patients contained s-erbB-2 concentrations similar to those of healthy blood donors. Patients with distant metastasis from advanced breast cancer had significantly higher values of s-erbB-2 in comparison to patients with non-disseminated disease (mean: 59.6 vs. $11.6 \mathrm{U} /$ $\mathrm{ml} ; \mathrm{p}=0.022$ ). A significant correlation was observed between s-erbB-2 serum levels and serum LDH concentrations $(p<0.001)$, levels of alkaline phosphatase $(p<$ 0.001 ), and the presence of hepatic metastasis ( $p=$ 0.001). Time to tumor progression was significantly shorter in patients with s-erbB-2 levels above $40 \mathrm{U} / \mathrm{ml}$ (mean: 23.4 vs. 56.7 months; $p=0.002$ ). Furthermore, breast cancer patients with hepatic metastasis and those
\end{abstract}

with elevated s-erbB-2 serum levels above $40 \mathrm{U} / \mathrm{ml}$ had limited response to hormone or chemotherapy. Nonresponders had significantly higher s-erbB-2 levels (mean: 270.3 , range: $42-500 \mathrm{U} / \mathrm{ml}$;) compared with the responder group (mean: 23.1, range: $0-149 \mathrm{U} / \mathrm{ml} ; \mathrm{p}<$ 0.001 ). Logistic regression analysis indicated that elevated s-erbB- 2 serum levels above $40 \mathrm{U} / \mathrm{ml}$ independently predicted an unfavorable response to second-line hormone or chemotherapy in patients with advanced metastatic breast cancer.

Copyright $\odot 2002$ S. Karger AG, Basel

\section{Introduction}

HER-2/c-erbB-2 is the human homologue of the rat $n e u$ oncogene and was originally identified in rat neuroblastomas. The c-erbB-2 oncogene encodes for a $185-\mathrm{kD}$ transmembrane receptor with tyrosine kinase activity which is closely related to the epidermal growth factor receptor. Recent findings indicate that activation of the HER-2 receptor is mediated by heterodimerization with receptors of the HER1, HER3, HER4 growth factor receptor family following ligand binding [1]. Amplification of the c-erbB-2 gene and overexpression of the pro-

\begin{tabular}{ll}
\hline KARGER & ( ) 2002 S. Karger AG, Basel \\
Fax +4161306 1234 34 -4283/02/0232-0070\$18.50/0 \\
$\begin{array}{l}\text { E-Mail karger@karger.ch } \\
\text { www.karger.com }\end{array}$ & $\begin{array}{l}\text { Accessible online at: } \\
\text { www.karger.com/journals/tbi }\end{array}$
\end{tabular}

R. Kopp, MD

Department of Surgery, Klinikum Grosshadern

Marchioninistrasse 15

D-81377 Munich (Germany)

Tel. +49 897095 1, Fax +49895664 
tein is associated with a poor prognosis in breast cancer patients [2-4]. Inhibition of erbB-2 activity by an antiHER-2 monoclonal antibody was shown to enhance chemosensitivity against tumor cells and improve clinical response rates in patients with metastatic HER/neu-overexpressing breast cancer [5-8].

The extracellular domain of the c-erbB-2 oncoprotein is released from tumor cells by proteolytic cleavage and detectable in supernatants of erbB-2-overexpressing tumor cell lines [9-12]. Determination of serum levels of shed c-erbB-2 oncoprotein in breast cancer patients showed increased soluble erbB-2 levels in patients with advanced breast cancer [13-17] associated with reduced response to adjuvant or neoadjuvant hormone or chemotherapy $[18,19]$. In patients with metastatic disease, elevated serum erbB-2 levels or erbB-2 overexpression in the tumor were associated with decreased response to firstline hormone or chemotherapy [20] or second-line hormone therapy [21]. However, in the study reported by Revillion et al. [22], levels of c-erbB-2 were not related to the response to chemotherapy in patients with advanced breast cancer.

Tumor progression following first-line hormone or chemotherapy is a major problem in patients with metastatic breast cancer. Predictive markers giving further information concerning the probable response regarding different treatment strategies would be of clinical interest. We have therefore determined soluble erbB-2 serum levels in an unselected group of patients with metastatic breast cancer receiving second-line hormone or chemotherapy in comparison to breast cancer patients without recurrent disease or healthy blood donors.

Serum levels of erbB-2 were compared with clinicopathologic parameters (e.g. patient age), parameters of the original primary tumor (e.g. tumor size), histopathological grading, nodal status, estrogen and progesterone receptor levels and serum levels of lactate dehydrogenase (LDH), alkaline phosphatase (ALP), time to tumor progression, the number of metastasized organs or presence of liver metastases.

\section{Patients and Methods}

Soluble human erbB-2 levels were measured by an ELISA purchased from Dianova (Hamburg, Germany). Serum samples were examined from 99 breast cancer patients with or without recurrent disease treated at the Departments of Internal Medicine III and Surgery, Klinikum Grosshadern, University of Munich, Germany. In addition, soluble erbB-2 levels were determined in serum samples from healthy blood donors. Serum samples were divided into aliquots and stored at $-70^{\circ} \mathrm{C}$ until analysis was performed.
In 72 breast cancer patients, a modified radical mastectomy with lymphadenectomy was performed. Patients with small tumors $(<2 \mathrm{~cm})$ and in the absence of contraindications (multifocal tumors, high intraductal component, lobular carcinomas or small breast volume) were treated by segmentectomy with lymphadenectomy and postoperative radiotherapy. Patients with lymph-node-positive tumors received an adjuvant hormone or chemotherapy (tamoxifen or cyclophosphamide, methotrexate and fluorouracil, CMF) in relation to their menopausal status. Patients developing distant metastasis during the follow-up were treated by first-line chemotherapy (usually CMF).

At the time of investigation, 35 breast cancer patients were without recurrent disease, while 64 had progressive disease with metastases located in the liver $(\mathrm{n}=11)$, lung $(\mathrm{n}=8)$, bone $(\mathrm{n}=21)$ or at multiple sites $(\mathrm{n}=24)$. All patients with metastatic disease received second-line hormone or chemotherapy because of tumor progression or relapse after an initial hormone or chemotherapy for metastatic disease. Response to hormone or chemotherapy was evaluated by WHO/UICC criteria.

The responder group included patients with complete or partial remission and patients with stable disease/no change, while nonresponders were patients with progressive disease showing objective criteria for tumor progression of at least $25 \%$. Thirty-eight patients received anti-estrogen therapy (usually tamoxifen), while 26 patients were treated by chemotherapy (Adriamycin plus cyclophosphamide or CMF). Response to therapy was evaluated after 6 months of treatment. Objective response to therapy (complete and partial responses) or no change was observed in 35/64 (54.7\%) patients investigated. Patients with locoregional tumor recurrences with or without distant metastases treated by surgery or local radiotherapy with or without additional hormone or chemotherapy were not included in the study.

Data were evaluated by ANOVA for comparison of mean values, the Wilcoxon test for nonparametric data and the $\chi^{2}$ test or Fisher's exact test. Results are expressed as means \pm SEM. Box blot diagrams show median levels with lower/upper quartiles and maximum/minimum values. All $\mathrm{p}$ values reported are two sided. Logistic regression was performed using diadochotomized variables using the following cutoff levels for each variable determined in a healthy control group (mean +2 SD): LDH $240 \mathrm{U} / \mathrm{ml}$; ALP $175 \mathrm{U} / \mathrm{ml}$, and soluble erbB-2 $40 \mathrm{U} / \mathrm{ml}$. In some patients parameters related to the primary tumor were not completely available (especially lymph node involvement or grading).

\section{Results}

We analyzed the sera of 35 non-metastatic and 64 breast cancer patients with progressive metastatic disease for soluble erbB-2 concentrations and evaluated their response to second-line hormone or chemotherapy. Levels of soluble erbB-2 were not related to parameters of the initial primary tumor, such as tumor invasion, lymph node involvement, grading or levels of estrogen or progesterone receptors (table 1). A significant correlation was observed between s-erbB-2 serum levels and serum LDH concentrations $(\mathrm{p}<0.001)$, levels of alkaline phosphatase 
Table 1. Soluble c-erbB-2 serum levels in correlation to clinical and histopathologic parameters

\begin{tabular}{|c|c|c|c|}
\hline \multirow{2}{*}{\multicolumn{2}{|c|}{ Parameters }} & \multicolumn{2}{|c|}{ Soluble c-erbB-2, U/ml } \\
\hline & & mean \pm SEM & $\mathrm{p}$ \\
\hline \multicolumn{4}{|c|}{ Primary tumor } \\
\hline \multicolumn{2}{|c|}{$\mathrm{T} 1 / 2$} & $41.5 \pm 11.6$ & \multirow{2}{*}{ NS } \\
\hline \multicolumn{2}{|l|}{$\mathrm{T} 3 / 4$} & $46.3 \pm 20.6$ & \\
\hline \multicolumn{2}{|l|}{ N negative } & $35.8 \pm 15.4$ & \multirow{2}{*}{ NS } \\
\hline \multicolumn{2}{|l|}{ N positive } & $46.1 \pm 13.2$ & \\
\hline \multicolumn{2}{|l|}{ G 2} & $27.5 \pm 12.8$ & NS \\
\hline \multicolumn{2}{|l|}{ G 3} & $75.4 \pm 25.8$ & 0.076 \\
\hline \multicolumn{2}{|c|}{$\mathrm{ER} \leq 20 \mathrm{fmol} / \mathrm{mg}$} & $58.6 \pm 16.5$ & \multirow{2}{*}{ NS } \\
\hline \multicolumn{2}{|c|}{$\mathrm{ER}>20 \mathrm{fmol} / \mathrm{mg}$} & $17.0 \pm 2.0$ & \\
\hline \multicolumn{2}{|c|}{$\mathrm{PgR} \leq 20 \mathrm{fmol} / \mathrm{mg}$} & $58.0 \pm 15.9$ & \multirow{2}{*}{ NS } \\
\hline \multicolumn{2}{|c|}{$\mathrm{PgR}>20 \mathrm{fmol} / \mathrm{mg}$} & $13.8 \pm 1.4$ & \\
\hline \multicolumn{4}{|c|}{ Progressive disease } \\
\hline \multirow[t]{2}{*}{ Age } & $<50$ years & $35.8 \pm 15.6$ & \multirow{2}{*}{ NS } \\
\hline & $\geq 50$ years & $45.9 \pm 12.9$ & \\
\hline \multirow[t]{2}{*}{ TTPr } & $<24$ months & $104.3 \pm 35.6$ & \multirow[t]{2}{*}{0.026} \\
\hline & $\geq 24$ months & $32.7 \pm 8.5$ & \\
\hline \multirow[t]{2}{*}{$\mathrm{LDH}$} & $<240 \mathrm{U} / \mathrm{ml}$ & $21.0 \pm 4.1$ & \multirow[t]{2}{*}{$<0.001$} \\
\hline & $>240 \mathrm{U} / \mathrm{ml}$ & $120.0 \pm 47.8$ & \\
\hline \multirow[t]{2}{*}{ ALP } & $<175 \mathrm{U} / \mathrm{ml}$ & $21.0 \pm 4.1$ & \multirow[t]{2}{*}{$<0.001$} \\
\hline & $\geq 175 \mathrm{U} / \mathrm{ml}$ & $120.1 \pm 47.8$ & \\
\hline \multirow[t]{2}{*}{ Metastasis } & 1 organ & $56.6 \pm 20.5$ & \multirow{2}{*}{ NS } \\
\hline & $>1$ organ & $64.8 \pm 22.4$ & \\
\hline \multirow{2}{*}{\multicolumn{2}{|c|}{$\begin{array}{l}\text { Non hepatic met. } \\
\text { Hepatic metastasis }\end{array}$}} & $24.42 \pm 4.5$ & \multirow[t]{2}{*}{0.001} \\
\hline & & $131.86 \pm 41.8$ & \\
\hline
\end{tabular}

Various clinical and histopathological parameters were correlated with the absence or presence of metastatic breast cancer disease. For quantitative or qualitative parameters, the mean values or percentages were calculated.

TTPr = Time to tumor progression; ER = estrogen receptor; $\mathrm{PgR}=$ progesterone receptor; $\mathrm{NS}=$ not significant.

$(\mathrm{p}<0.001)$, and the presence of hepatic metastasis $(\mathrm{p}=$ 0.01 ). Time to tumor progression was significantly reduced in patients with s-erbB-2 levels above $40 \mathrm{U} / \mathrm{ml}$ (mean: 23.4 vs. 56.7 months; $p=0.002$ ).

Sera of non-metastatic breast cancer patients contained s-erbB-2 concentrations similar to those of healthy blood donors (mean: $9.2 \mathrm{U} / \mathrm{ml}, \mathrm{n}=17$ ). In patients with distant metastasis from recurrent breast cancer, significantly higher values of s-erbB-2 were detected in comparison to patients with non-disseminated disease (mean values: 59.6 vs. $11.6 \mathrm{U} / \mathrm{ml} ; \mathrm{p}=0.022$, table 2 , fig. 1 ).

To investigate the predictive value of soluble erbB-2 levels regarding the response to therapy, CD44v6 levels determined in 64 patients with advanced metastatic breast cancer at the beginning of second-line hormone or
Table 2. Determination of various clinical and histopathological parameters in patients with and without metastatic breast cancer

\begin{tabular}{lllll}
\hline Characteristics & \multicolumn{2}{l}{ Breast cancer patients } \\
\cline { 2 - 3 } & non-metastatic & & metastatic & $\mathrm{p}$ \\
\cline { 2 - 2 } mean \pm SEM $\mathrm{n}$ & & mean \pm SEM $\mathrm{n}$ \\
\hline
\end{tabular}

\section{Primary tumor}

$\mathrm{T} 1 / 2$

T $3 / 4$

$\mathrm{N}$ negative

$\mathrm{N}$ positive

G 2

G 3

$\mathrm{ER}, \mathrm{fmol} / \mathrm{mg}$

$\mathrm{PgR}, \mathrm{fmol} / \mathrm{mg}$

Progressive disease

Age, years $\quad 54.2 \pm 1.8$

$\mathrm{LDH}, \mathrm{U} / \mathrm{ml} \quad 147.9 \pm 4.6$

ALP, $\mathrm{U} / \mathrm{ml} \quad 93.5 \pm 4.7$

s-erbB-2, U/ml $11.6 \pm 0.7$

$26 \quad 46$

9

12

23

24

11

$48.7 \pm 8.9$

1

32

$58.48 \pm 14.7$

$43.48 \pm 16.7$

46 NS

$\mathrm{ER}=$ Estrogen receptor; $\mathrm{PgR}=$ progesterone receptor; $\mathrm{NS}=$ not significant.

chemotherapy were related to the response to therapy. Responsiveness to therapy was assessed by WHO/UICC criteria. Patients with metastatic disease were divided into two groups, one with positive erbB-2 serum levels (above $40 \mathrm{U} / \mathrm{ml}$ ) and the other with negative erbB-2 serum levels (below $40 \mathrm{U} / \mathrm{ml}$ ). The frequency of responders was $32 / 38(84.2 \%)$ in the group with low soluble erbB2 levels and $3 / 26(11.5 \% ; \mathrm{p}<0.001)$ in the group of patients with high erbB-2 serum levels. As shown in table 3, patients not responding to second-line hormone or chemotherapy had elevated mean levels of LDH $(446.8$ vs. $190.5 \mathrm{U} / \mathrm{ml} ; \mathrm{p}=0.001)$ or $\operatorname{ALP}(334.8$ vs. $187.8 \mathrm{U} / \mathrm{ml}$; $\mathrm{p}=0.015)$, increased levels of s-erbB-2 (270.3 vs. $23.1 \mathrm{U} /$ $\mathrm{ml} ; \mathrm{p}<0.001$; fig. 2) and more frequently hepatic metastasis $(18 / 29$ vs. $8 / 35 ; p=0.01)$ in comparison to the responder group. So far, we did not observe differences in the response to therapy between the patients treated either by hormone or chemotherapy with respect to erbB-2 serum levels.

Logistic regression analysis including LDH, ALP, presence of hepatic metastasis and soluble erbB-2 levels $(>40$ $\mathrm{U} / \mathrm{ml}$ ) as variables indicated that only elevated s-erbB-2 serum levels above $40 \mathrm{U} / \mathrm{ml}$ independently predicted an unfavorable response to second-line hormone or chemotherapy $(p=0.001)$ in patients with recurrent metastatic breast cancer. 
Fig. 1. Levels of s-erbB-2 were determined in the sera of breast cancer patients followed up after tumor resection: 35 patients were without distant metastasis (non-metastatic), while 64 patients had developed metastases in the liver, bones, lungs or at multiple sites. Fig. 2. Levels of soluble erbB-2 are shown in patients without evidence of clinical response to hormone or chemotherapy for metastatic breast cancer (non-responder group; $\mathrm{n}=29$ ) in comparison to patients with objective criteria of response to therapy (responder group; $\mathrm{n}=35$ )

Table 3. Correlation between response to therapy and clinical and histopathological parameters

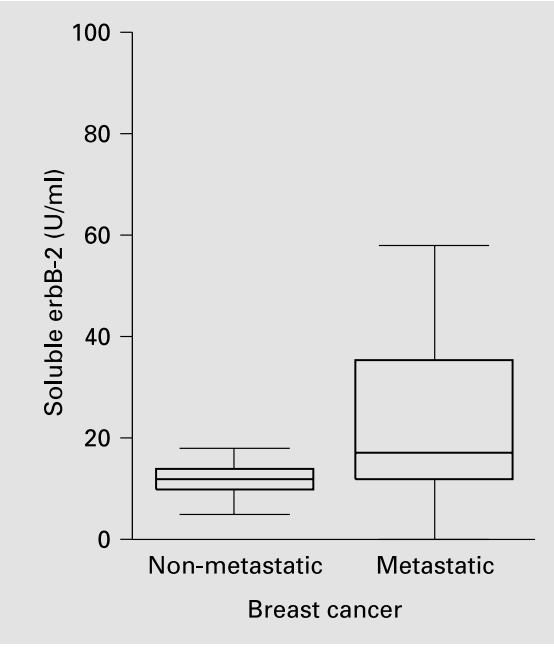

2

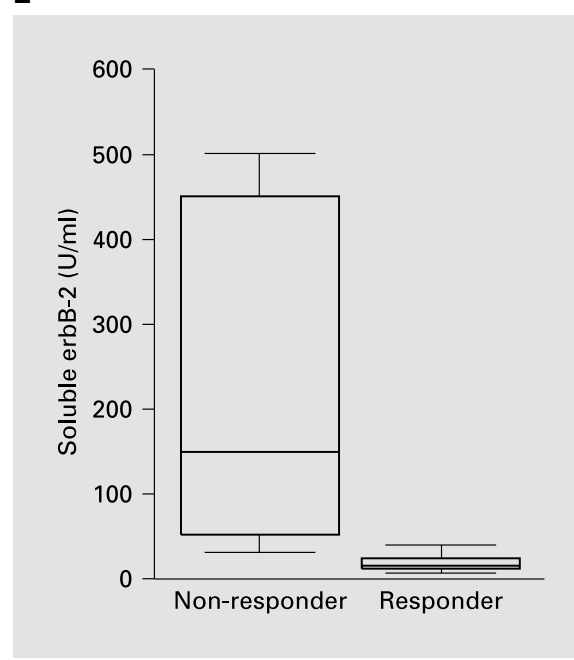

\begin{tabular}{|c|c|c|c|c|c|}
\hline \multirow[t]{2}{*}{ Characteristics } & \multicolumn{2}{|l|}{ Responder } & \multicolumn{2}{|c|}{ Non-responder } & \multirow[t]{2}{*}{$\mathrm{p}$} \\
\hline & mean & $\mathrm{n}$ & mean & $\mathrm{n}$ & \\
\hline \multicolumn{6}{|l|}{ Primary tumor } \\
\hline $\mathrm{T} 1 / 2$ & & 25 & & 21 & \multirow{2}{*}{ NS } \\
\hline $\mathrm{T} 3 / 4$ & & 10 & & 8 & \\
\hline $\mathrm{N}$ negative & & 14 & & 6 & \multirow{2}{*}{ NS } \\
\hline N positive & & 12 & & 14 & \\
\hline $\mathrm{G} 2$ & & 14 & & 8 & \multirow{2}{*}{ NS } \\
\hline G 3 & & 16 & & 16 & \\
\hline $\mathrm{ER}, \mathrm{fmol} / \mathrm{mg}$ & \multicolumn{2}{|l|}{$88.4(0-549)$} & \multicolumn{2}{|c|}{$41.1(0-283)$} & NS \\
\hline $\mathrm{PgR}, \mathrm{fmol} / \mathrm{mg}$ & \multicolumn{2}{|l|}{$73.52(0-742)$} & \multicolumn{2}{|c|}{$7.7(0-30)$} & NS \\
\hline \multicolumn{6}{|c|}{ Progressive disease } \\
\hline Age, years & \multicolumn{2}{|l|}{$54.3(34-76)$} & \multicolumn{2}{|c|}{$55.3(39-75)$} & NS \\
\hline TTPr, months & \multicolumn{2}{|l|}{$52.7(0-233)$} & \multicolumn{2}{|c|}{$24.1(2-62)$} & NS \\
\hline $\mathrm{LDH}, \mathrm{U} / \mathrm{ml}$ & \multicolumn{2}{|l|}{$190.5(119-430)$} & \multicolumn{2}{|c|}{$446.8(135-1219)$} & 0.001 \\
\hline ALP, $\mathrm{U} / \mathrm{ml}$ & \multicolumn{2}{|l|}{$187.8(0-1,452)$} & \multicolumn{2}{|c|}{$334.8(124-514)$} & 0.015 \\
\hline s-erbB-2, U/ml & \multicolumn{2}{|l|}{$23.1(0-149)$} & \multicolumn{2}{|c|}{$270.3(42-500)$} & $<0.001$ \\
\hline \multicolumn{6}{|l|}{ Metastases } \\
\hline 1 organ & & 23 & 17 & & \multirow{2}{*}{ NS } \\
\hline$>1$ organ & & 12 & 12 & & \\
\hline Hepatic & & 8 & & 18 & \multirow{2}{*}{0.01} \\
\hline Non-hepatic & & 27 & & 11 & \\
\hline
\end{tabular}

For abbreviations, see table 1. Ranges in parentheses.

\section{Discussion}

Progressive metastatic disease is a major problem in patients with breast cancer. Predictive factors would be of clinical interest to indicate the probability of a favorable response to various treatment modalities. However, few data are available investigating the predictive value of tumorbiologic factors regarding the response to secondline therapy in breast cancer patients with advanced metastatic disease. Estrogen and progesterone receptor levels were reported to define the response to hormone therapy in patients with advanced breast cancer [23]. Foekens et 
al. [24] have shown a poor response to tamoxifen therapy in patients with recurrent breast cancer and overexpression of the urokinase-type plasminogen activator and its inhibitor PAI-1. The amplification of the HER-2/neu oncogene leading to c-erbB2 protein overexpression and increased serum levels was implicated in several studies with early tumor recurrence, poor prognosis [2-4, 13-17] and unfavorable response to first-line endocrine therapy $[18,19]$ in breast cancer patients.

Based on the study of Leitzel et al. [21] reporting a correlation between serum erbB-2 levels and the response to second-line hormone therapy in metastatic breast cancer, we analyzed soluble erbB-2 levels in patients with advanced metastatic disease receiving second-line hormone or chemotherapy. Our data indicate an unfavorable response to second-line hormone or chemotherapy in patients with progressive metastatic breast cancer and elevated serum erbB-2 levels. Increased erbB-2 serum levels were additionally associated with clinical signs of progressive malignant disease as indicated by reduced time to tumor progression and the presence of liver metastasis. Therefore, these breast cancer patients with advanced metastatic disease do not seem to profit from standard hormone or chemotherapy.

However, the results of other studies investigating the role of serum erbB-2 levels regarding the response to adjuvant or first-line chemotherapy in breast cancer patients are controversial. These reports $[25,26]$ seem to indicate an improved response to adjuvant or first-line chemotherapy in breast cancer patients with elevated erbB-2 levels using doxorubicin, CMF and paclitaxel as chemotherapeutic substances. In contrast, other studies indicate an association of elevated soluble erbB-2 levels with unresponsiveness of advanced breast cancer patients to anthracyclines or CMF treatment [4, 20]. Furthermore, Colomer et al. [27] have shown in a prospective study the predictive value of circulating HER2/erbB-2 levels in patients with advanced breast cancer associated with reduced efficacy to first-line paclitaxel-doxorubicin-based chemotherapy. Based on the results of previous reports and our study, we conclude that tumor progression following first-line chemotherapy might select breast cancer subtypes with erbB-2 overexpression leading to reduced responsiveness to second-line chemotherapy even by substances reported to be effective during adjuvant or first-line treatment. Therefore, analysis of soluble erbB-2 in the sera of breast cancer patients with advanced disease and tumor progression following first-line chemotherapy might be of predicitive value to select patient subgroups with unfavorable response to standard hormone or chemotherapy.
Although the treatment of patients with metastatic breast cancer with monoclonal antibodies against the p185 c-erbB-2 oncoprotein alone or in combination with various chemotherapy protocols was reported to improve response to therapy and patient outcome [5-8], recent experimental evidence has shown reduced efficacy of anti-erbB-2 antibodies in the treatment of tumor cells with high levels of shed s-erbB-2, due to neutralizing effects [28].

Therefore, the selection of patients with low serum levels of shed erbB-2 might be relevant to improve the response to anti-erbB-2 antibody treatment. Furthermore, new strategies are needed to improve the clinical outcome of these patients. These might include attempts to specifically target the immunogenic profile of tumors with erbB-2 overexpression [29, 30] or modify the receptor-activated tyrosine kinase signal by specific inhibitors or interaction with proteins involved in negative receptor regulation $[1,31]$.

Elevated levels of soluble erbB-2 were associated with a reduced time to tumor progression. However, based on our study, we cannot conclude that elevated s-erbB-2 serum levels might predict an early relapse following firstline therapy for metastatic disease. Prospective studies will have to investigate the predictive role of s-erbB-2 levels during the follow-up of patients with advanced breast cancer with respect to tumor progression and prognosis.

Our analysis of soluble erbB-2 levels in patients with advanced metastatic breast cancer receiving standard hormone or chemotherapy indicates that the determination of erbB-2 serum levels seems to be of predictive value with respect to response to therapy. However, further innovative treatment strategies will be necessary to improve the outcome of these patients with advanced metastatic breast cancer and otherwise poor prognosis.

\section{Acknowledgment}

The authors wish to thank E. Doischer for excellent technical assistance. 


\section{References}

1 Menard S, Tagliabue E, Campiglio M, Pupa SM: Role of HER2 gene overexpression in breast carcinoma. J Cell Physiol 2000;182: 150-162.

2 Slamon DJ, Clark GM, Wong SG, Levin WJ, Ulrich A, Mc Guire WL: Human breast cancer: Correlation of relapse and survival with amplification of the HER-2/neu oncogene. Science 1987;235:177-182.

3 Muss HB, Thor AD, Berry DA, Kute T, Liu ET, Koerner F, Cirrincione CT, Budman DR, Wood WC, Barcos M, Henderson IC: c-erbB-2 expression and response to adjuvant therapy in women with node-positive early breast cancer. N Engl J Med 1994;330:1260-1266.

4 Gusterson BA, Gelber RD, Goldhirsch A, Price KN, Säve-Söderborgh J, Anbazhagan R, Styles J, Rudenstam C-M, Goloough R, Reed R, Martinez-Tello F, Tiltman A, Torhorst J, Grigolta P, Bettelheim R, Neville AM, Bürki K, Castiglione M, Collins J, Lindtner J, Senn HJ, for the International (Ludwig) Breast Cancer Study Group: Prognostic importance of c-erbB2 expression in breast cancer. J Clin Oncol 1992;10:1049-1056.

5 Baselga J, Tripathy D, Mendelsohn J, Baughmann S, Benz CC, Dantis L, Sklarin NT, Seidman AD, Hudis CA, Moore J, Rosen PP Twadell T, Henderson IC, Norton L: Phase II study of weekly intravenous recombinant humanized anti-p185HER2 monoclonal antibody in patients with HER2/neu-overexpressing metastatic breast cancer. J Clin Oncol 1996;14:737-744

6 Baselga J, Norton L, Albanell J, Kim YM, Mendelsohn J: Recombinant humanized antiHER2 antibody (Herceptin) enhances the antitumor activity of paclitaxel and doxorubicin against HER2/neu overexpressing human breast cancer xenografts. Cancer Res 1998;58: 2825-2831.

7 Pegram MD, Lipton A, Hayer DF, Weber BL, Baselga JM, Tripathy D, Baly D, Baughman SA, Twaddell T, Glaspy JA, Slamon DJ: Phase II study of receptor-enhanced chemosensitivity using recombinant humanized antip185HER2/neu monoclonal antibody plus cisplatin in patients with HER2/neu-overexpressing metastatic breast cancer refractory to chemotherapy treatment. J Clin Oncol 1998;16: 2659-2671.

8 Pegram MD, Konecny G, Slamon DJ: The molecular and cellular biology of HER2/neu gene amplification/overexpression and the clinical development of herceptin (trastuzumab) therapy for breast cancer. Cancer Treat Res 2000; 103:57-75.

9 Mori S, Mori Y, Mykaiyama T, Yamada Y, Sonobe Y, Matsushita H, Sakamoto G, Akiyama T, Ogawa M, Shiraishi M: In vitro and in vivo release of soluble erbB-2 protein from human carcinoma cells. Jpn J Cancer Res 1990;81:489-494.
10 Langton BC, Crenshaw MC, Chao LA, Stuart SG, Akita RW, Jackson JE: An antigen immunologically related to the external domain of gp 185 is shed from nude mouse tumors overexpressing the c-erbB-2 (HER-2/neu) oncogene. Cancer Res 1991;51:2593-2598.

11 Lin YZ, Cliton GM: A soluble protein related to the HER-2 proto-oncogene product is released from human breast carcinoma cells. Oncogene 1991;6:639-643.

12 Pupa SM, Menard S, Morelli D, Pozzi B, De Palo G, Colnaghi MI: The extracellular domain of the c-erbB-2 oncoprotein is released from tumor cells by proteolytic cleavage. Oncogene 1993;8:2917-2923.

13 Leitzel K, Teramoto Y, Sampson E, Mauceri J, Langton BC, Demers L, Popdczaski E, Harvey H, Shambaugh S, Volas G: Elevated soluble cerbB-2 antigen levels in the serum and effusions of a proportion of breast cancer patients. J Clin Oncol 1992;10:1436-1443.

14 Kath R, Hoffken K, Otte C, Metz K, Scheulen ME, Hulskamp F, Seeber S: The neu-oncogene product in serum and tissue of patients with breast carcinoma. Ann Oncol 1993;4:585-590.

15 Isola JJ, Holli K, Oksa H, Teramoto Y, Kallioniemi OP: Elevated erbB-2 oncoprotein levels in preoperative and follow-up serum samples define an aggressive disease course in patients with breast cancer. Cancer 1994;73:652658.

16 Kandl H, Seymour L, Bezwoda WR: Soluble cerbB-2 fragment in serum correlates with disease stage and predicts for shortened survival in patients with early-stage and advanced breast cancer. Br J Cancer 194;70:739-742.

17 Krainer M, Brodowicz T, Zeillinger R, Wiltschke C, Scholten C, Seifert M, Kubista E, Zielinski CC: Tissue expression and serum levels of HER-2/neu in patients with breast cancer. Oncology 1997;54:475-481.

18 Carlomagno C, Perrone F, Gallo C, De Laurentiis M, Lauria R, Morabito A, Pettinato L, Dántonio A, Bianco R, De Placido S: c-erbB2 overexpression decreases the benefit of adjuvant tamoxifen in early-stage breast cancer without axillary lymph node metastasis. J Clin Oncol 1996;14:2702-2708.

19 Wright C, Nicholson S, Angus B, Sainsbury JRC, Farndon J, Cairns J, Harris AL, Horne CHW: Relationship between c-erbB-2 protein product expression and response to endocrine therapy in advanced breast cancer. Br J Cancer 1992;65:118-121.

20 Vargas-Rodig LM, Gago FE, Tello O, De Civetta MTM, Ciocca R: c-erbB-2 (HER-2/neu) protein and drug resistance in breast cancer patients treated with induction chemotherapy. Int J Cancer 1999;84:129-134.
21 Leitzel K, Teramoto Y, Konrad K, Chinchilli VM, Volas G, Grossberg H, Harvey H, Demers L, Lipton A: Elevated serum c-erbB-2 antigen levels and decreased response to hormone therapy of breast cancer. J Clin Oncol 1995;13: 1129-1135.

22 Revillion F, Hebbar M, Bonneterre J, Peyrat JP: Plasma c-erbB2 concentrations in relation to chemotherapy in breast cancer patients. Eur J Cancer 1996;32A: 231-234.

23 Osborne CK, Yochmowitz MG, Knight WA III, Mc Guire WL: The value of estrogen and progesterone receptors in the treatment of breast cancer. Cancer 1980;46:2884-2888.

24 Foekens JA, Look MP, Peters HA, van Putten WLJ, Portengen $\mathrm{H}$, Klijn JGM: Urokinasetype plasminogen activator and its inhibitor PAI-1: Predictors of poor response to tamoxifen therapy in recurrent breast cancer. J Natl Cancer Inst 1995;87:751-756.

25 Paik S, Bryant J, Park C, Fisher B, Tan-Chiu E, Hyams D, Fisher ER, Lippmann ME, Wickerham DL, Wolmark N: erbB-2 and response to doxorubicin in patients with axillary lymph node-positive, hormone receptor negative breast cancer. J Natl Cancer Inst 1998;90: 1361-1370.

26 Thor AD, Berry DA, Budman DR, Muss HB, Kute T, Henderson IC, Barcos M, Cirrincione C, Edgerton S, Allred C, Norton L, Liu ET: erbB-2, p53, and efficacy of adjuvant therapy in lymph node-positive breast cancer. J Natl Cancer Inst 1998;90:1346-1360.

27 Colomer R, Montero S, Lluch A, Ojeda B, Barnadas A, Casado A, Massuti B, Cortes-Funes $\mathrm{H}$, Lloveras B: Circulating HER2 extracellular domain and resistance to chemotherapy in advanced breast cancer. Clin Cancer Res 2000;6: 2356-2362.

28 Brodowicz T, Wiltschke C, Budinsky AC, Krainer M, Steger GC, Zielinski CC: Soluble HER-2/neu neutralizes biologic effects of antiHER-2/neu antibody on breast cancer cells in vitro. Int J Cancer 1997;73:875-879.

29 Suzuki T, Anderegg B, Ohkawa T, Irie A, Engebraaten O, Hallks-Miller M, Holm PS, Curiel DT, Kashani-Sabet M, Scanlon KJ: Adenovirus-mediated ribozyme targeting of Her-2/neu inhibits in vivo growth of breast cancer cells. Gene Ther 2000; 7:241-248.

30 Wright M, Grim J, Deshane J, Kim M, Strong TV, Siegal GP, Curiel DT: An intracellular anti-erbB-2 single chain antibody is specifically cytotoxic to human breast carcinoma cells overexpresing erbB-2. Gene Ther 1997;4:317322.

31 Fiorentino L, Pertica C, Fiorini M, Talora C, Crescenzi M, Castellani L, Alema S, Benedetti $\mathrm{P}$, Segatto O: Inhibition of erbB-2 mitogenic and transforming activity by RALT, a mitogeninduced signal transducer which binds to the ErbB-2 kinase domain. Mol Cell Biol 2000;20: 7735-7750. 